\title{
Communication Satellites: International Organization for Development and Control
}

\author{
Stephen E. Doyle*
}

$\mathrm{T}$ THE USE OF COMPUTERS, transistors, laser apparatus and new metals and plastics to solve old and new problems have implications for social scientists well beyond the reach of our present understanding. Technology moves swiftly but society adjusts slowly at times to accommodate the changes. As the benefits of the new technology are applied, there must be careful and continual maintenance of domestic and international order, for technology may, at any moment, be redirected toward the production of war material.

The imtroduction of satellites as a technological advance in commumications has caused unusual problems. In the past the main effect of technological innovation lias been the occasional disruption of the balance of power in the world community. ${ }^{1}$ As a result, economic, political and legal structures have periodically become obsolete or unworkable and new structures have been designed in response. In contrast, the problem posed by communication satellites is the organization of an international cooperative to develop and exploit this pervasive communications system.

This article exammes the Communications Satellite Corporation, the entity developed domestically to represent the interests of the United States in establishing a global communication satellite system, and INTELSAT, ${ }^{2}$ the international organization entrusted with the pronotion, establishment and operation of sucli a system. The article also explores some of the pohicy problems which will become increasingly difficult as satellite technology advances, including the questions of private ownership of satellites and direct broadcasting from satellites.

* B.A., 1960, University of Massachusetts; LL.B., 1963, Duke University; Member of the Bar of the District of Columbia. All views expressed herein are those of the author and are not attributable to any organization with which he is now or has been associated.

1 Other symposia evaluating the impact of science on law include several papers of interest. See, e.g., Nationat Aeronadtics \& Stace Adm'n, Proceedings of the Conference on the LaW of Space and of Satertite Comomunications (1964); Conference on Space Science and Space LaW, Proceentigs of the Conference at tee Untversity of OkLaHOMra, JUNE, 1963 (M. Schwartz ed. 1964); Law, Science and Technology: A Symposium, 33 Geo. Wase. L. Rev. 1-456 (1964).

2 International Telecommunications Satellite Consortiun. 


\section{I}

ORGANIZATIONAL REQUIREMENTS OF A COMMUNICATIONS SATELLITE SXSTEM

The introduction of communication satellites has quickened processes which historically have moved rather slowly. We learned in 1946 that radio signals could be bounced off passive objects in space (such as the moon) and relayed to distant points on the earth. ${ }^{3}$ By the late 1950's, experimental programs ECHO, SCORE, RELAY, TELSTAR and SYNCOM followed one another in rapid-fire succession. ${ }^{4}$ The United States Congress, aware in 1959 that communication satellite technology was developing rapidly, ${ }^{5}$ could not define a "global commercial communication satellite system" but sensed that one would emerge. Only twentyseven months elapsed between July 1962, when the Bell Telephone Laboratory's TELSTAR satellite first transmitted experimental television to Europe ${ }^{6}$ and October 1964, when live television coverage of the Tolyyo Olympic Games was relayed via SYNCOM III across the Pacific to North America. ${ }^{7}$ Within this short period of time nations managed to organize an intergovernmental global cooperative program to exploit communication satellite technology. Final approved agreements were initialled in Washington, D.C., during July $1964,{ }^{8}$ only twenty-four months after the first successful experiments with an active communication satellite.

\section{- A. - Meeting Organizational Needs Domestically}

The problem demanding resolution in 1961-1962 was the creation of an entity which would represent the best interests of the United States

3 E. EMame, Aeronautics and Astronadtics 1915-1960, at 55 (1961). Use of the moon as a relay station for intercontinental transmission made from Jodrell Bank, England, to the U.S. Air Force Caunbridge Research Center at Bedford, Mass., on May 14, 1959, is reported at 109 .

4 There are many sources recounting early developmental work in satellite communications. A good brief summary can be found in Hearings on Commercial Communications Satellites Before the Subcomm. on Applications and Tracking and Data Acquisition of the House Comm. on Science and Astronautics, 87th Cong., 2d Sess., ser. 16 (1962). Recent developments are reviewed in Hearings on Progress in Space Communications Before the Subcomm. on Communications of the Senate Comm. on Commerce, 89th Cong., 2d Sess., ser. 87-78, pt. 1 (1966).

${ }^{5}$ See Hearings on Satellites for World Communication Before the House Comm. on Science and Astronautics, 86tb Cong., 1st Sess., ser. 9 (1959); H.R. REP. No. 343, 86th Cong., 1st Sess. 6-7 (1959).

${ }^{6}$ An historical summary can be found in House Comar. on ScIence and AStronadtics, 88tir Cong., 1st Sess., Report on Astronautical and Aeronadtical Events of 1962, at 95, 117 (Comm. Print 1963).

7 See Nationat Aeronadtics \& Space Adm'n, Astronautics and Aeronattics, 1964, at 258-59, 347 (1965).

$8 I d$. at 260. 
in promoting, establishing and operating a global communication satellite system. Alternatives considered by Congress included government ownership, ${ }^{9}$ a communications common carrier consortium, ${ }^{10}$ and a private corporation wholly owned by public stockholders. ${ }^{11}$ The compromise proposal adopted in 1962 was a blend of private industry and government interests. ${ }^{12}$ Congress authorized creation of the Communications Satelhte Corporation (ComSat), to be owned one-half by telephone and telegraph companies (the carriers) and one-half by public stockholders, in Title III of the Communications Satellite Act of $1962 .{ }^{13}$ The Communications

9 For a summary of the legislative history of the act finally adopted and an analysis of the act itself, see Legislation Note, The Communications Satellite Act of 1962, 76 HARv. L. REv. 388 (1962). The proposal for government ownership was embodied in bills including S. 2890, 87th Cong., 2d Sess. $\$ \$ 2,4 b$ (1962), proposed by Senator Kefauver for himself and Senators Morse, Yarborough, Gore, Gruening, Burdick and Neuberger. For the minority views of Senators Yarborough and Bartlett to S. REP. No. 1584, 87th Cong., 2d Sess. 49 (1962) (Senate Conimittee on Commerce) and of Senators Morse, Long and Gore to S. Rep. No. 1873, 87th Cong., 2d Sess., pt. 2 (1962) (Senate Committee on Foreign Relations), see Rosenblum, Regulation in Orbit: Administrative Aspects of the Communications Satellite Act of 1962, in Nationat Aeronautics \& Space Adm'n, Proceedings of the Conference on the Law of Space and of Satellite Conanunications 111-12 (1964).

10 The communications common carrier ownership approach grew out of an inquiry conducted by the Federal Communications Commission. During the investigation an Ad Hoc Carrier Committee was created to make recommendations on the organizational scheme to be adopted domestically. The carrier group submitted a formal Report of the Ad Hoc Carrier Conmittee, dated October 12, 1961. This report is discussed in Rosenblum, supra note 9, at 118-19. The carrier ownership proposal was the essence of the bill (S. 2650 $\S 402 \mathrm{E}$ ) introduced by Senator Kerr on January 11, 1962.

11 S. 2814, 87th Cong., 2d Sess. § 401c (1962), was introduced by Senator Kerr for himself and Senator Magnuson. It was the initial adninistration proposal calling for private ownership of the proposed corporation. S. 2814 is discussed in S. REP. No. 1319, 87th Cong., 2d Sess. 2-9 (1962) (Senate Committee on Aeronautical and Space Sciences) and in S. REP. No. 1584, 87th Cong., 2d Sess. 9, 13 (1962) (Senate Committee on Commerce).

12 See S. Rep. No. 1584, 87th Cong., 2d Sess. (1962) (Senate Committee on Commerce) for a complete report on the final bill as adopted by the Congress. For a good summary of comnunication satellite developments and a discussion of organizational alternatives open to Congress, see Hearings on S. 2650 and S. 2814 Before the Senate Comm. on Aeronautical and Space Sciences, 87th Cong., 2d Sess. (1962). Commentary on the act adopted can also be found in Doyle, International Satellite Communications and the Law, 11 McGIl L.J. 137 (1965); Johnson, Satellite Communications: The Challenge and the Opportunity for International Cooperation, 19 FED. CoM. B.J. 88 (1965); Levin, Organization and Control of Conmuntications Satellites, 113 U. PA. L. REv. 315 (1965); Mansbach, The "Authorized Entity"- "Authorized User" Question in the Communications Satellite Act of 1962, 20 FED. Corr. B.J. 117 (1966); Moulton, Commercial Space Communications, in Law and PolrTics IN SpaCe 23 (M. Cohen ed. 1964); Segal, Communications Satellites-Progress and the Road Ahead, 17 Vand. L. Rev. 677 (1964); Strassburg, Space Communications-A New Chapter in Regulation, in Pubitc Utritty Section of the AMrerican Bar Ass'iv, Report 23 (1963). A comprehensive bibliography of relevant commentary on commumication satellite law and policy up to 1963 appears in Law ANd Politics in Space 193-97 (M. Cohen ed. 1964). A sociological overview of domestic and international problems and prospects appears in Conarunication Sateditte Systems Technorogy ch. 6 (R. Marsten ed. 1966).

1376 Stat. 419 (1962). 
Satellite Act represents one of the few times in our history that Congress has directed the creation, organization and management structure of a private corporation.

ComSat is both a private business for profit and a government-regulated enterprise..$^{14}$ Organized and incorporated under the laws of the District of Columbia, ComSat is an organization which, in the words of its officers,

views itself as an entity created by the United States Government for a very special purpose. This purpose is to represent the United States in connection with the Nation's first commercial venture into space. ComSat is mindful of the fact that the establishment of a private corporation for profit, which would undertake a venture of such magnitude and of such importance to the United States, is of special significance because of the position of the Nation as the free world's major proponent of private enterprise.

Because of these considerations, ComSat views itself as having been granted a trust of national importance. In addition to being charged with the interests of its shareholders, it considers itself as having been eharged also, in its area of charter, with the best interests of the United States in the broadest sense. We should make clear that we do not view this latter investiture of special trust as a substitute for trusts placed in the hands of various elements of the Government of the United States, but rather as a supplement to them. ${ }^{15}$

Thus, ComSat came into existence as a private corporation for profit, but with a responsibility to represent the United States' best interests in an international cooperative venture of undetermined nature.

\section{B. Meeting Organizational Needs Internationally}

ComSat became a jural entity on February 1, 1963, just five months after President John F. Kennedy signed into law the Communications Satellite Act of $1962 .{ }^{16}$ Negotiations between the United States and other nations concerning cooperation in the establisliment of a global commumication satellite system began in earnest in $1963 . .^{17}$ The International Agreement Establishing Interim Arrangements for a Global Commercial Communications Satellite System was initialled during July 1964 and

14 For a view of the extent to which agencies in the federal government are involved in programs and projects of the Communications Satellite Corporation, see 76 Stat. 421 (1962).

15 Statement of the Comnumications Satellite Corporation 3-4, dated and filed August 1, 1966, in F.C.C. Doc. No. 16495, In the Matter of the Establishment of Domestic NonConmon Carrier Communication-Satellite Facilities by Non-Governmental Entities, 5 F.C.C. 2d 354 (1966).

1676 Stat. 419 (1962).

17 U.S. Dep't of State Press Release No. 328, July 17, 1964, in 51 Dep'T State Butr. 167 (1964). 
opened for signature in August 1964.18 This agreement produced an international consortium which provided a framework for multinational participation in the design, development, construction, maintenance, operation and ownership of the initial global commercial communication satellite system. ${ }^{19}$ Althougl all nations participating in the consortium are represented by governmentally owned or supervised telecommunication entities, the consortium itself is a partnership arrangement possessing an identity distinct from its participating members. ${ }^{20}$

The 1964 agreement is only an agreement for interim arrangement. As pointed out in detail below, ${ }^{21}$ the agreement requires re-examination during 1969, directed toward the establishment of permanent arrangements. Before considering the re-examination phase, however, it will be useful to set forth in some detail the substance of the arrangements which now exist.

For operational purposes, the global satellite system is divided into a "space segment" and earth stations which transmit traffic to and receive traffic from the satellites. The space segment comprises the satellites in space and terrestrial tracking and control facilities necessary to operate the satellites from the earth. The individual earth stations are owned and operated independently, usually by interests in the nation in which they are located. Technical standards to be met by earth stations and

18 Text of the agreement can be found in 51 DeP'T STATE BuLL. 282-90 (1964); $30 \mathrm{~J}$. ATR L. \& CoMr. 270 (1964). In April 1965, the world's first commercial commumication satellite was launched. On June 28,1965 , it entered commercial operation providing a direct communication link between North America and Europe. National Aeronadtics \& Space Adn'N, Astronadtics and Aeronatutics, 1965, at 128, 172, 197, 300-01 (1966).

$19 \mathrm{~A}$ nunuber of papers relating to the international and policy aspects of organizing for commercial satellite communications were presented in Athens, Greece, September 14-15, 1965, at the Eighth Colloquium on the Law of Outer Space, organized by the International Institute of Space Law, an organ of the International Astronautical Federation. The papers are collected in A. Halex \& L. Schwartz, Proceedings of the Eightr Collopuiun on THE LAW OF OUTER Space (1966). A description of the ComSat-INTELSAT arrangements is contained in: Staff of tae Senate Conar. on Aeronadtical and Space Sciences, RepORT ON INTERnationat, CoOperation and Organization for OUTER Space, S. Doc. No. 56, 89th Cong., 1st Sess. 50 (1965). Criticism of the ComSat-INTELSAT arrangements is described and discussed in Staff of the Senate Comas. on Aeronadtical and Space ScIences, 89th Cong., 2D Sess., Report on Soviet Space Programs, 1962-65, at 474, 508 (Conin. Print 1966).

20 Pursuant to the 1964 Agreement on Interim Arrangements, each of the government signatories to the agreenrent also signed, or designated a national telecommunication entity to sign, a Special Agreement. This agreement details the financial commitunents of the participating operational entities and provides details of system management responsibilities and procurement activities. Predictably, subsequent commentary has both approved and disapproved of the Agreement for Interim Arrangements. The text of the Special Agreenent is set forth in sources cited in note 18 supra.

21 See text acconupanying notes 32-34 infra. 
the rates and conditions for use of the satellites are determined by the governing organ of the international consortium. ${ }^{22}$

The present consortium whicls owns and manages the space segment of the system, is a form of partnership arrangement operated for profit and participated in, as of this writing, by fifty-five nations. ${ }^{23}$ Eacli member is represented by a governmental or commercial telecommunication entity. ComSat is the United States participant. The primary policyunaking body in INTELSAT ${ }^{24}$ is the Interim Comununications Satellite Committee (ICSC). Member nations are represented on the ICSC on a quota basis, ${ }^{25}$ with each nation that owns one and one-half per cent or more of the total system accorded one seat. Members with less than one and one-half per cent ownership may aggregate their quotas to a total of one and one-lialf per cent or more, and thus seat a representative on the Committee. On December 31, 1966, there were seventeen members of the ICSC representing forty of the fifty-five nnember nations. ${ }^{26}$ The Committee meets on a regular basis, every six to eight weeks, and makes the

22 Istvan, Organization and Program of INTELSAT, in CoMcMunication SATELLtTe Systears Technology 929 (R. Marsten ed. 1966). The following two paragraphs in the text are based upon material in Mr. Istvan's paper.

23 Participants in the International Telecommunications Satellite Consortium on December 31, 1966, included: Algeria, Argentina, Australia, Austria, Belgium, Brazil, Canada, Ceylon, Chile, China, Colombia, Denmark, Ethiopia, France, Germany, Greece, India, Indonesia, Iraq, Ireland, Israel, Italy, Japan, Jordan, Kuwait, Lebanon, Lybia, Licchtenstein, Malaysia, Mexico, Monaco, Morocco, The Netherlands, New Zealand, Nigeria, Norway, Pakistan, The Philippines, Portugal, Saudi Arabia, Singapore, South Africa, Spain, Sudan, Sweden, Switzerland, Syria, Thailand, Tunisia, United Arab Republic, United Kingdom, United States, Vatican City, Venezuela, Yemen. Comanunicatrons Sateritte Corporatron, Report to the Prestoent aNd the Congress for tHe CaLendar Year 1966, app. I, at 18-22 (1967).

24 International Telecommunications Satellite Consortium.

25 The quota assigned each member nation is primarily determined on the basis of a predicted percentage of world telephone traffic for that country in 1968, Quotas currently range from slightly more than fifty-three per cent for the United States to less than onehalf per cent for the Principality of Monaco. Comanuntcatrons Sateritte Corporatron, Report to the Presdent and the Congress for the Calendar Year 1966, at 20, 22 (1967). As new members join the consortium, each existing member suffers a pro rata reduction of its quota. However, once seated on the ICSC, no nation can be unseated by a subsequent reduction of its quota to less than one and one-half per cent to accommodate new members. If every country in the world joins the consortium, the United States quota, under the existing arrangements, would be reduced to approximately 50.5 per cent.

26 The United States is currently the dominant INTELSAT participant. It holds a majority voice in voting. Each ICSC representative has a vote equal to the quota of the nation or nations he represents. The designated entity of the United States (ComSat) manages the system on behalf of all members. The favorable position of the United States resulted from several factors present in 1963-1964, including among others: its leadership in communication satellite technology, availability of investment capital to meet initial mvestınent demands of the operational system, sufficient launch capacity to place required payloads in desired orbits, and the initiative of United States Government and industry officials. 
major policy and planning decisions for the establishment and operation of the global system. By the terms of the Agreement on Interim Arrangements, ComSat is designated manager of the system on behalf of the members, and it executes and adnninisters the orders and directives of the ICSC. For example, a decision by the ICSC to purchase a given satellite, or group of satellites, will be implemented by ComSat. The corporation negotiates the contract and signs it on behalf of INTELSAT, under authority vested in it by the Committee.

The novelty of the arrangements entered into for the establishment of the global system in 1964 justifies a re-examination of the arrangements after an initial operating period of reasonable length. After five years of operating experience, the nations involved could bring to a conference table experience, satisfaction, frustration or complaints. However, experience with the operational global system will not be the only product of the years 1964-1969. On June 14, 1962, a group of nine European nations signed in Paris a convention to create the European Space Researcl Organization (ESRO). This organization is to promote collaboration among European nations in space research and technology, exclusively for peaceful purposes. ${ }^{27}$ Similar organizational efforts led to the contemporaneous creation of a European Launcher Development Organization (ELDO) to develop and construct space vehicle launchers and equipment suitable for practical applications. ${ }^{28}$ In addition to these government programs there is a Eurospace organization involving major Western European industrial concerns. This association is also developing programs for operational and research space systems, including refinement of communication satellite teclnology. ${ }^{29}$

In Eastern Europe, the Soviet Union is progressing with its communication satellite program, and the socialist nations of the world are actively developing, independent of the West, an international program for satellite communications. ${ }^{30}$

27 Staff of the Senate Coagr. on aeronautical and Space Sctences, Report on Internationat CoOperation and Organization for OUTer Space, S. Doc. No. 56, 89th Cong., Ist Sess. 105 (1965).

28 Id. at 112. See also Beller, ELDO to Provide ComSat Launcher, Tecrnodogy Week, July 18,1966 , at 20 .

29 Staff Report, sutpra note 27 , at 123 .

30 Staff of the Senate Conar. on aeronautical and Space Scrences, 89th Cong., 2D Sess., Report on Soviet Space Programs 1962-65, at 327-29, 767-72 (Comm. Print 1966).

The official Soviet news agency Tass reported on April 15, 1967, that space experts from the Soviet Union, East Germany, Bulgaria, Cuba, Mongolia, Poland, Romania, Hungary and Czechoslovakia liave worked out a cooperative program of space research, including development of an international communications satellite system. Scientists from these nine countries plan to cooperate in experiments deahing with outer space problems as 


\section{Incompatibility: A Potential Bar to Global Integration}

A technical problem of increasing importance involves the potential incompatibility of satellite systems established by different nations. The French and Russians, for example, use a television broadcasting standard and telecommunication equipment different from the standards and equipinent used in the United States and other nations. Despite long months of negotiations, the International Telecommunication Union (ITU) has been unable to establish acceptable European standards for television receivers, either black and white or color. Tlus, working out the problem of integration of multiple satellite systems when they become operational could be a inajor problem. Russian and French authorities have made little, if any, effort to establisli agreement with the Uuited States or other major communication markets on the technical standardization of their communication satellite systems.

If the task of establishing standards and criteria for international integration of satellite systems is left to the ITU, the lack of any real teeth in the ITU Convention to enforce compliance with its mandates may result in frustration for that international body. ${ }^{31}$ If several systems are launched, their integration will depend upon the willingness of national officials to agree upon integration. The ITU could not do the job alone.

INTELSAT management officials may hope that considerations of

well as in the joint launching of satelites and rockets. N.Y. Times, April 17, 1967, at 10, col. 5 .

An indication of Soviet determination in this regard is found in the following excerpt from an article by A. Yakovlev, entitled Television: Problems and Perspectives, originally published in Russian in the September 1965 issue of Kommunist, the official organ of the Central Committee of the Communist Party of the U.S.S.R. An English translation by R. D. Crane reads: "Soviet television has expanded beyond the Western borders of our country. And it would be short-sighted to let the borders of the U.S.S.R. himit the tasks of the projected development of television. With the development of communications satellites the plans for the creation of 'World Television' [as distinct from the Soviet Bloc organization known as "Intervision"] have become real. This will mean the open clash of two ideologies in space. And here there is only one possibility: victory!" Kommunist, Sept. 1965, at 80 (translation in letter from Robert D. Crane to John Johnson, Sept. 22, 1965).

There is reportedly 1.7 million dollars in the 1967 French national budget to start the $\$ 30$ million Stationary Orbit Radio Satellite (SAROS) project, in which French authoritics plan to produce one or two prototype and then two operational synchronous communication satellites. The French are planning a SAROS launch in 1971 from their French Guiana launch facilities now under construction. The French SAROS project is also exciting industrial interests in other countries, especially Germany. Beller, ELDO to Provide Comsat Launcher, TrCHNOLOGY WEEK, July 18, 1966, at 20; Johnsen, France Backs UN INTELSAT Control, Aviation WeEK \& Space Tecenologx, Feb. 13, 1967, at 26.

31 For discussion of the ITU's inability to coerce even payment of financial obligations by its members to the organization, see G. Coddng, The Internatronal TelecomanumiCATKON UNION 438 (1952). 
financial economy, which will result from avoidance of duplicate facilities, and technical economy in consumption of limited available radio spectrum, will militate in favor of sensible cooperative effort on a global scale. However, national prestige and security, desires for autonomy and pride may well lead Russia and France to forego the economies of a simgle system in favor of "French Flag" or "Russian Flag" communication satellites. Economists and engineers are not always listened to by their politicians.

II

\section{A CRITICAL REAPPRAISAL IN CHANGED CIRCUMSTANCES}

The 1964 Agreement on Interim Arrangements provides that within one year after the initial global system becomes operational, and in any case not later than January 1, 1969, the ICSC shall render a report to all members of INTELSAT. The report is to contain ICSC recommendations concerning definitive arrangements to be established by the new agreement. The report is to present all shades of opinion and is to consider, among other things, whether the interim arrangements should be continued on a pernianent basis, or whether a permanent international organization with a general conference and an international administrative staff should be established. ${ }^{32}$

It is required in the 1964 agreement that: (1) regardless of the form of the definitive arrangements to be adopted, their aims shall be consonant with the principles set forth in the preamble to the 1964 agreement; (2) the new arrangements shall be open to all nation members of the International Telecommunication Union or their designated entities; (3) the new arrangements shall safeguard the investment made by signatories of the 1964 agreement; and (4) they shall be such that all parties to the arrangements may have an opportunity to contribute to the determination of general policy..$^{33}$

Within three months following submission of the ICSC report to the INTELSAT members, the United States is to convene an international conference to consider the report. Duly designated communication entities nay participate at the conference which is to formulate definitive arrangements at the earliest practicable date, with a view to their entry into force by January $1,1970 . .^{34}$ It is worth noting that the Agreement on Interim Arrangements does not terminate until superseded. If there is no agreement on definitive arrangements in 1969, the existing arrangeInents will continue in force.

32 Agreement on Interim Arrangements for a Global Commercial Communications Satellite System, art. IX. See note 18 supra.

33 Id.

34 Id. 
When the conferees assemble in 1969 to consider the progress made in the first five years of commercial satellite communications, the nature of things to come, and the alternative methods of organizing to implement the principles set forth in the preamble to the 1964 agreement, the circumstances of discussion will be greatly changed from what they were in 1963-1964. Western European nations will have made substantial progress in their programs for developing communication satellite technology. There may be by 1969 a satellite launching capacity in Western European hands, developed either independently by France or cooperatively through multinational effort. An operable communication satellite system will very likely have been established by the Soviet Union, and there will probably be more active participation in the discussion by the smaller developing nations whicl are currently making major efforts to equip themselves to participate in a global satellite system. With two or three possible launch options open to nations, or groups of nations, seeking to launch communication satellites; with significantly higher levels of technical achievement in satellite construction and sophistication predictable for both Western Europe and the Soviet Union; and with an emerging voice from the developing nations becoming a more potent political and economic factor, the United States will be discussing international organizational questions in a wholly different environment from that in which it negotiated in 1963-1964.

\section{A. Some Organizational Alternatives}

Although it has been reported in several sources that ComSat officials are happy with existing international arrangements and hope for only shight modifications in $1969,{ }^{35}$ it has become apparent that other nations are not ready to reaffirm the interim arrangements without, at least, a long, hard look at alternative arrangements.

The pressures leading to the 1969 reappraisal are already being felt in major capitals around the world. Industrial and government officials alike are talking about when and how the initial global system will work, but they are thinking hard about the impact of initial success on 1960. The provision of hardware for the continuing system, the construction of earth stations around the world, and the extent to which individual nations will be able to participate in control and management of the system are matters requiring careful study. Such study must be underway now in every country concerned about the outcome of the 1969 conference. It is possible that the quasi-governmental business enterprise, INTELSAT, will be reconstituted as an international agency such as the

35 Coughlin, The Comsat Question, TecrnoroGy WEEK, Oct. 24, 1966, at 50; Johnsen, supra note 30 , at 26 . 
International Civil Aviation Organization. This seems less likely, however, than the possibility that INTELSAT's basic structure will be maintained with only shight modifications to accommodate, at least ostensibly, more participation by smaller nations in policy-making. Logic seems to dictate that the nations of the world will act to ensure that the most economical, efficient, reliable system possible will be established and maintained. The continuation with modifications of the existing arrange- ' ments which work very well seems far more bikely than a total overhaul and construction de novo of an international agency.

It is unlikely, however, that socialist nations will participate significantly in INTELSAT as it is now structured. The socialist nations will very likely organize a competing counterpart to INTELSAT, economic and technical considerations to the contrary notwithstanding. And despite the mefficiency and undesirable duplication of cost and effort involved, it is also possible that regional arrangements will emerge, within or outside of INTELSAT, for the establishment of regional satellite systems on a cooperative basis.

It has also been reported that "France is unofficially advocating a United Nations satellite communications agency to manage a global system and supersede [INTELSAT]. ${ }^{336}$ Unless such an approach is followed, it is predicted, there will be

an Intelsat global satellite communications system and an antiIntelsat global system, dominated by [the] USSR, and then, perhaps, a proliferation of systems. This would be contrary to the position of the U.S. government in favor of a single global system. It would be carrying on a cold war in telecommunications. ${ }^{37}$

Reasoned analysis, lowever, indicates that there are many more than two organizational alternatives.

Maintaining the status quo after 1969 would be maintaining an international business consortium, with ownership quotas for participants, estabhished and operated under an intergovernmental agreement. In such a structure, the United States could maintain a strong position of leadership, since quotas are determined by the share of traffic generated, and the United States generates a large share of international telecommunication traffic.

The other extreme alternative would be a United Nations type of organization with a one-nation-one-vote principle of participation. There could be a General Assembly and an Executive Council, probably having an internationally constituted secretariat-manager group which would operate the satellite system. If the status quo is unacceptable to Euro-

36 Johnsen, supra note 30 , at 26.

37 Id. 
peans and developing nations in Asia and Africa, they will move toward the one-nation-one-vote alternative. Presumably the United States will not want to lose its dominance and will therefore avoid a one-nationone-vote organization in favor of the status quo.

A multiplicity of alternative organizational forms lies between these two extremes. In its current position, the United States enjoys a commanding voice, a complete veto, management control and relatively little opposition. Management control by ComSat is likely to be the hardest fought issue in 1969. The United States may sacrifice willingly a slare of its voice to give other nations higher quotas. And it may have to give up its absolute veto. The trade-off of greatest significance will be the veto versus control. If managenient control is not retained in the United States, it is very likely that the United States will insist upon the veto.

\section{B. The United States' Position in 1969}

The United States' basic philosophy for 1969 should be the offering of proposals which other nations will consider acceptable, but which will incorporate a measure of rehance upon its capital, competence and direction. Progress in satellite technology outside the United States will continue, but for the foreseeable future that progress will not be as technically advanced as that in the United States. The United States will therefore still have a definite advantage, but nowhere near the degree it enjoyed in this respect in 1963-1964.

Because the United States generates, or handles in transit, close to a majority of the international telecomnunication traffic in the world, its position is one of power. However, temperance and patience dictate that other nations must be given a real sense of and basis for participation in any definitive arrangements adopted. International communication requires international cooperation. The price the United States must pay for cooperation is allowance of participation by other countries, on more than a token basis, in the establishment, ownership, operation and control of the global conmercial communication satellite system.

\section{III}

\section{CONTINUTNG CONTROVERSY}

There are continuing problems which will not be completely resolvable in 1969 because bigger and better satellites are and will be in the offing. Technicians have publicly forecast the development of direct broadcast satellites. ${ }^{38}$ These satellites will be able to broadcast directly to home radio and television receivers simultaneously in areas including

38. Conaruntcation Sateitite Systears Technology ch. 4 (R. Marsten ed. 1966). 
millions of square miles. This high-power broadcast satellite will present such policy problems as: who is to control the satellite itself; who will own, maintain, and derive profit from it (if, in fact, profits are to be derived); and, under what conditions and by whom may a satellite, transmitting programs into nations which do not want them or cannot tolerate their political or social implications, be jammed or destroyed? These are difficult problems. They are no less immediate because the satellites which will create them are not yet built. Unfortunately, they are not likely to be faced until such a satellite is about to be built, launched or made operable.

Men sometimes seem to believe that if difficult questions are ignored they will either dissolve or resolve themselves in time. The nations of the world cannot ignore the problems of an impending conference to reconsider organizational arrangements in 1969, because in terms of planning and preparation, the 1969 issues are already upon them. Unfortunately, they cannot look mucl beyond 1969, because the achievements of technology in 1970 and thereafter are not sufficiently defined to permit the social scientists to attack the problems to be generated by technology.

\section{A. Public Versus Private Enterprise in Space}

Russian and East European commentary on ComSat and INTELSAT has been consistently caustic. At all available international forums, leading spokesmen, official and unofficial, have assailed the United States' attitude permitting private enterprise $\mathrm{m}$ space. ${ }^{39}$ This point of view is not limited to East Europeans, ${ }^{40}$ although they have been the most vociferous critics.

There has also been substantial debate in the United States and in the United Nations concerning the appropriateness of authorizing private enterprise to exploit space technology for commercial purposes. The controversy over private versus public ownership of communication satellites was highlighted in Congress during debates on the Communications Satelhite Act of $1962 .{ }^{41}$ Senator Estes Kefauver favored and ardently championed the proposal for a national Communication Satellite Authority. The effort was in vain. However, the decision of the Congress to authorize creation of ComSat and to permit ComSat to engage in commercial exploitation of space was not the end of the matter.

Prior to negotiation of the recently signed Treaty Governing the Exploitation and Use of Outer Space, Including the Moon and Other Celes-

${ }^{39}$ See sources cited in note 19 supra.

40 See, e.g., comments by Maxwell Cohen (then Director, Institute of Air \& Space Law, McGill University, Montreal, Canada) in National Aerowautics and Space AdMmNIstration Conference on the Law of Space and of Sateudite Condmunicattons 53-54 (1964).

41 See note 9 supra. 
tial Bodies, ${ }^{42}$ the Soviet Union urged that activities in space be limited to national governments so that no private enterprise would be allowed to exploit space commercially. ${ }^{43}$ The United States and other nations argued in favor of a more liberal attitude. ${ }^{44}$ The dialogue on this point resulted in a compromise provision included in the treaty as article VI, which reads as follows:

States Parties to the Treaty shall bear international responsibility for national activities in outer space, including the moon and other celestial bodies, whether such activities are carried on by governmental agencies or by non-governmental entities, and for assuring that national activities are carried out in conformity with the provisions set forth in the present Treaty. The activities of non-governmental entities in outer space, including the moon and other celestial bodies, sliall require authorization and continuing supervision by the State concerned. When activities are carried on in outer space, including the moon and other celestial bodies, by an international organization, responsibility for compliance with this Treaty shall be borne both by the international organization and by the States Parties to the Treaty participating in such organization. ${ }^{45}$

The primary thrust of article VI is the fixing of international responsibility for activities in outer space. A national government is responsible for space activities of the government and non-governmental entities of that particular nation. And, when activities are conducted in space by an international organization (such as INTELSAT), responsibility for compliance with the treaty, international law and the United Nations Charter rests upon both the international organization and the nations which are parties to the treaty and participants in the organization. Thus, ultimate responsibilty for all mankind's activities in space may be laid at the door of one or more national governments.

The United States preserved the right for its private enterprise to exploit space by agreeing to the principle that each national government is responsible for its activities in space and those of its citizens and any

42 Text and background documentation are contained in StafF REPORT OF THE SENATE Cosar. on Aeronautical and Space Sciences, 90th Cong., Ist Sess., Treaty on PrinCIPLes Governing the Activities of States IN the Exploration and Use of OUTER Space, Including the Moon and Other Celestial Bodies (Comm. Print 1967).

43 This position was put forth by the U.S.S.R. representative in proceedings of the Umited Nations Committee on Peaceful Uses of Outer Space, preceding adoption of the General Principles endorsed by the United Nations General Assembly in 1963. See G.A. Res. 1962, 18 U.N. GAOR Supp. 15, at 15, U.N. Doc. A/5549/Add. 1 (1963).

44 Extensive discussion on this point and on the topic of competitive claims to uses of outer space is contained in Law and Poutrics IN Space (M. Cohen ed. 1964); H. TAUbeNFELd, SPACE AND Socnety (1964); Estep \& Kearse, Space Communications and the Law: Adequate International Control After 1963?, 60 MrcE. L. Rev. 873 (1962).

45 See note 42 supra. 
organizations participated in by that government or its citizens. Given such arrangements it may become academic to discuss further the problems of public versus private exploitation of space relating to responsibility.

It still is appropriate, however, to consider further the benefits of permitting private interests in nations with a highly developed space industry to exploit outer space commercially. In this observer's view, space exploration will be supported substantially by the hope for potential commercial exploitation. Absent profit motivation, it may be seriously debated whether the abstract challenge of new knowledge, new horizons and new experience will be sufficient to sustain a series of multi-bilion dollar national or international programs to learn more about the mysteries of cislunar and translunar space.

If, as some observers suggest, it could have been foreseen that allowance of private enterprise in the space arena would give rise to problems otherwise avoidable, ${ }^{46}$ the decision to permit private exploitation should have been based upon a weighing of the advantages and disadvantages of permitting private interests in space. That, however, was probably not the basis upon which article VI of the 1966 Space Treaty was drafted. It is more likely that the decision to allow private exploitation was the result of a profit motive underlying the dominant voice of the United States in the United Nations proceedings. The question of private interests in space is, however, no longer debatable, because more than sixty nations have signed a treaty which expressly recognizes a role for private enterprise in space. One might abstractly evaluate the justifications and implications of the decision, but there is no denying that it is now a fait accompli.

\section{B. Direct Broadcast Satellites}

A direct broadcast satellite is a satellite capable of transmitting a signal directly to a receiver, such as a radio or television set in the home, without requiring a middle-point relay facility, such as a local radio or television station. The present state of communication satellite technology makes possible the use of satellites for distribution of a radio or television signal from one point to one or more other points when, after the signal is strengthened, it can be rebroadcast to home receivers. Such a system is termed a "distribution satellite system."

46 See, e.g., sources cited in notes 19 and 40 supra.

${ }^{47} \mathrm{~A}$ variety of distribution satellite systems have been proposed, and are described in detail, in comments filed in August and December 1966 in FCC Docket No. 16495, by the American Broadcasting Companies, the American Telephone and Telegraph Company, the Communications Satellite Corporation, the Ford Foundation, and the Western Union Telegraph Company. See 5 F.C.C.2d 354 (1966). 
broadcasting satellite will eliminate the need for an intermediary, signalstrengthening, local relay. Expert predictions of the earliest date for possible operation of direct broadcast satellites vary, but it is generally agreed that such a satellite will be available, or "within the state of the art" by 1975.48

Before 1975 national and international attention will have to be focused closely on the potential legal and policy problems posed by a direct broadcast satellite. Richard N. Gardner, Professor of Law and International Relations at Columbia University and a former State Department official connected with the negotiation of the 1964 Agreement on Interim Arrangements, summarized what he calls "the lieart of the political problem" in two sentences:

Countries with no immediate prospect of carrying on space broadcasting fear that the United States and the Soviet Union may use this technology to send their people political or commercial messages that the governments do not like. Unless we can allay their fears about unilateral penetration of their populations and give them an interest in the use of this technology for their own benefit, we may never get broadcast satellites off the ground.98

Professor Gardner's statement may be considered by some to be unduly alarming. Arguably, it would be inconsistent with the international recognition of sovereigu governments for one nation to violate the national territorial integrity of another nation by bombardment with words from space. However, the possibility that direct broadcast satellites may be so used by major powers is creating concern in foreign countries. It is reported that in France, for example, there is concern that European mdependence, including its economic, cultural and political future, may be at stake. ${ }^{50}$ Another, similar view was voiced in an article appearing in The Economist of April 1, 1966, where it was written:

Governments will have no more control over the programs beamed to their populations than Mr. Benn [British Postmaster General] has now over Britam's private radios. ... In the interests of free speech and expression, can Europe even risk a world dominated by Soviet and American television-beamed propaganda without attempting to make its own voice heard?51

Such fears appear based in large part on current experience with broadcasting agencies such as the Voice of America, the British Broad-

48 See Comanumication Satelitie System Tecennology ch. 4 (R. Marsten ed. 1966).

49 Gardner, Space Broadcasting: Problems of International Law and Organization, Paper Presented at the AIAA Communications Satellite Systems Conference, May 2-4, 1966, Washington, D.C., at 7 (typed copy). The paper may be obtained from its author.

50 TIME, May 6, 1966, at 102.

51 THE Econounst, March 26-April 1, 1966, at 1206. 
casting Corporation and Radio Moscow. Professor Gardner, however, argues that satellite broadcasting is a significant extension of such programs. ${ }^{52}$ He points out that unlike short-wave radio broadcasting, programs beamed from space will be indistinguishable in their quality of reception froin locally broadcast programs. Also, television programs directed into a nation from space will have substantially greater psychological impact than current short wave radio broadcasts. ${ }^{53}$

Although officials in the ITU are considering the problem; it is not likely that adoption of an ITU regulation prohibiting space broadcasting would have any more salutary effect than existing prohibitions against ship-borne and aircraft-borne radio station operations now have on an active "pirate radio" industry.

The whole topic is obviously politically loaded and potentially explosive. Governments have avoided formal discussion of means to control space broadcasting as long as possible. The time to take some action to resolve the problems engendered by the developing technology is now upon us. Professor Gardner, for one, has proposed an eight-point program to be commenced in the United States immediately for the purpose of meeting the challenges broadcast satellites offer. ${ }^{54}$ Briefly summarized, his proposal is to: (1) move ahead with development of technical competence in the field; (2) encourage international consideration and understanding of both the potential benefits and problems of broadcast satellites; (3) assist in organization of pilot projects under international auspices to demonstrate the great potential of space broadcasting; (4) stimulate international banks and agencies to support financially facility construction and technical training in lesser developed countries; (5) reassure friendly governments that the United States will not use space facilities to send political or commercial messages into their countries; (6) take action through the United Nations and UNESCO to promote cooperative development of space broadcasting; (7) seek decisions in the ITU for allocation of frequencies for space broadcasting; and (8) support efforts to use space communication technology to bring the story and explain the functions of the United Nations to the people of the world. ${ }^{55}$

In the long-term analysis of space broadcasting problems, work will be required to establish equitable and effective regulating procedures.

ธ2 Gardner, supra note 49 , at 8.

$53 I d$.

54 Id. at 11-13.

55 Id. See also Staff of the Senate Comm. on Aeronadtical and Space Sctences,

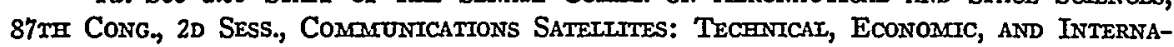
tional Developanents 120 (Comm. Print 1962). 
Such regulation will be exclusively from a technical standpoint and will involve frequency allocation, standards for compatibility, and agreement on rates and charges (if such services are to be on a commercial basis) and on the ownership and operational aspects of internationally shared facilities. A second area requiring cooperation will be programming. How nations will cooperate to formulate the form and content of programs to be broadcast from space facilities will be a difficult problem to resolve. Given the nature of national interests-economic, political, cultural and religious - a great deal of mutual understanding and patience will be required to attain agreement on programming to be beamed from satellites. And if agreement in these areas cannot be reached, nations will turn from cooperative ventures to self-lielp.

How can satellites in space be prevented from violating national integrity with radio or television broadcasts? Jamming, destruction of satellites, independent economic or political sanctions, and counterbroadcasts are means which might be considered by the offended state. Jamming of frequencies used would probably be the simplest, least costly and least likely to involve further response from the original antagonist. Destruction of a satellite for the foreseeable future will be a response available to very few nations. The breaking of diplomatic relations or termination of trade would be more severe forms of response because they involve impact on other areas of international relations.

\section{CONCLUSION}

If hope is placed in the United Nations-hope that it may become the focal point for international regulation, coordination and cooperation for joint use of space communication facilities-the world is likely to be disappointed. The international community is not yet mature enough to deal with such problems on a logical, common sense basis. Nationalism, racism, regionalsm and many more "isms" play too great a part in the formulation of law and policy today to permit ecumenicalism to dictate by "right reason" how we should live together in the world community. Slowly, maturity is being attained by some nations; unfortunately, however, not by enough of them. Eventually, the point may be reached when the interests of each man will be in balance with the interests of all men, and the interests of each nation may be placed in balance with the interests of all nations. It is to be hoped fervently that such a world can be built using the gifts of technology. 